\title{
APLN wt Allele
}

National Cancer Institute

\section{Source}

National Cancer Institute. APLN wt Allele. NCI Thesaurus. Code C104097.

Human APLN wild-type allele is located in the vicinity of Xq25 and is approximately $10 \mathrm{~kb}$

in length. This allele, which encodes apelin protein, plays a role in immunity and the negative regulation of HIV-1 infection. 